\title{
Overcoming Advocacy
}

\author{
The Honorable Robert H. Henry*
}

Jurisprudential Jedi Master (and perhaps Guitar Hero) Bryan Garner credits Aristotle, the great Greek trinitarian (small " $t$ "), with a surprisingly remarkable invention: the realization that each speech has three parts: a beginning (or introduction), a middle, and an end. ${ }^{2}$ This is the beginning.

\section{THE BEGINNING}

In this section I shall do three things. First, I will thank my hosts, the Dean and her fine law school. Second, I will acknowledge the donorthe Founder of our Feast - one of our Circuit's fine law firms. Third, and finally, as far as the beginning goes, I will tell you what I plan to cover in the middle of my speech, which also has three parts. To the task!

First, I do indeed want to thank Dean Agrawal for her kind introduction, but more for her risk-taking in inviting me to present this inaugural lecture. This is a good month and year for inaugurations, and I just came from a rather expansive one in Washington, D.C. In the press release announcing this fine center on advocacy, your dean made several perceptive statements which bridge gaps and bear repeating now. She said:

Much ink has been spilled about the divide between the practicing bar and the legal academy .... While I don't join the chorus of those who lament the relationship between the educational and the practicing arms of our profession, I do agree that our shared profession is stronger when

\footnotetext{
* Chief Judge, United States Court of Appeals for the Tenth Circuit. Eschew the use of footnotes for substantive matter in persuasive writing at all costs! I am using them here because this is a law review essay, and thus I need citations of authority, as well as diversions, to occupy the particularly rigid realm of legal journal writing. As to the meaning of this title, the reader should decide. Presumably, overcoming advocacy is better than regular ol' advocacy, and overcoming advocacy might also include the kind of "ethical" rhetoric that lawyer advocates, being officers of the court, should provide.

2. Bryan A. Garner, Garner on LANGUAGE AND Writing 4 (2009). Or as the Greeks would say, the prooemium, the prothesis, and the epilogos.
} 
we create opportunities to work together on the preparation of the next generation of lawyers, law professors and judges. It is an important task - perhaps one of the most crucial ones we undertake - that none of us can do alone.... The center will create not a physical, but an intellectual space for an ongoing dialogue and shared teaching mission between the KU law school and practicing lawyers.

I will return to these sentiments a bit later, but I fully embrace them now. Legal advocacy, and the ethics that must accompany it, requires both the academy and the bar to teach and foster. Dean, I commend you and the Law School for this endeavor.

Second, I want to acknowledge the donors who made this center possible. Shook, Hardy, \& Bacon, L.L.P. is a very prominent law firm. One of the things I most admire about it is its dedication to the profession through providing pro bono services. The legal community notices such things. Indeed, the firm has a full-time director of pro bono activities and an active pro bono committee. Its charity and success have been noted; I know that the Florida Immigrant Advocacy Center has honored the firm for its pro bono efforts in this most difficult field, dealing with, as the Torah puts it, "the stranger that dwelleth with you." commitment to represent those who cannot obtain or afford representation, especially those that may have very difficult cases, reflects the overall ideal that every sincere and serious litigant-rich or poor, unpopular or acclaimed, deserves representation - an ideal perhaps once more popular and practiced than it is now.

Also, as this Center for Excellence in Advocacy evidences, the firm actively acknowledges that ethics requires that lawyers should be good advocates, and know how to write and speak professionally. They are right; the Model Rules of Professional Conduct explain why we are here: "A lawyer shall provide competent representation to a client. Competent representation requires the legal knowledge, skill, thoroughness and preparation reasonably necessary for the representation." ${ }^{5}$ Competent representation requires not only following court rules for format, content,

3. Press Release, Univ. of Kan. Sch. of Law, New Law Sch. Ctr. to Promote Excellence in Legal Advocacy (June 13, 2008), http://www.law.ku.edu/media/news/stories/2008 /center_for_excellence.shtml (emphasis added).

4. Leviticus 19:34 (King James); see also RoBert Alter, The Five BooKs of Moses 630 (2004) ("Like the native among you shall be the sojourner who sojourns with you ....").

5. Model Rules of Prof'L CONDUCT R. 1.1 (2002). 
page length, and appendices; it also requires an ability in advocacy. ${ }^{6}$ Thus, advocacy that is not competent violates these model rules.

Now, as promised, I come to the end of the beginning, where I will tell you what I hope follows. Our subject today is advocacy, and presumably includes what it is and how to use it, how to create advocacy that overcomes, and how to overcome opposing advocacy.

We know that as lawyers we advocate for those interests we represent, but we often forget to whom our advocacy is directed and do not take into account our audience and how to persuade it. This is one of the greatest mistakes I see in appellate advocacy and, as I will later discuss, I am not alone.

I am going to start with the Greeks (Aristotle in particular) and explain why I think we should look to them in creating "overcoming" advocacy that persuades your audience. Second, and Aristotle would be happy with this, I want to talk about some of the ethics inherent in legal advocacy, which will show why the Dean was right, and must be right in her remark that I quoted earlier. ${ }^{7}$

\section{THE MIDDLE: "[I]T WAS GREEK TO ME.",}

In my view, the art of professional legal advocacy is best understood as being virtually synonymous with what Aristotle termed the "art of rhetoric." Aristotle's Rhetoric, written over 2300 years ago, is still considered to be the first, and perhaps the middle and last, word on the topic. The book itself is a hard read, probably because it is a community effort - at least partially a collection of Ari's or his students' notes from his lectures on the subject, so the inmates ran the asylum. This, coupled with the difficulty of translating his precise Greek terms into modern English, makes the reader's task daunting without some help. But it is a veritable encyclopedia of persuasion and merits review. Perhaps recognizing this, some law schools have recently begun to include courses on rhetoric in their curricula; you can be sure these courses carefully examine Aristotle.

Aristotle cleverly assumed his definition of rhetoric: "[1]et rhetoric be [defined as] an ability, in each [particular] case, to see the available

6. See, e.g., Thomas Haggard, Good Writing as a Professional Responsibility, 8 SCRIBES J. LEgal WritiNG 159, 159 (2002) ("Procedural rules often go beyond content and format, and address the required style of some pleadings."); see also MODEL RULES OF PROF'L CONDUCT R. 1.1 (2002).

7. See supra note 3 and accompanying text.

8. William Shakespeare, The Tragedy of Julius CAESAR act 1, sc. 2. 
means of persuasion." The great depth of Aristotle's coverage of the topic certainly exceeds my grasp and our time limitations, but I want to talk about his overarching theme, and the three attributes that are the means of persuasive advocacy.

As I stated at the outset, Aristotle was something of a trinitarian who often seemed to categorize things in threes. ${ }^{10}$ Thus, he indicated that a speech required three things - a speaker, a subject, and an audience - and he labeled three kinds of public speaking, based not upon the style of the speech, but upon the audiences addressed. The categories indicate audiences that are deliberative (like a legislature), or forensic (like a court or jury, or perhaps we might use the word "judicial"), and ceremonial (the Greek word epideictic referred to ceremonial speeches, such as Pericles's famous funeral oration-the oration that greatly influenced Lincoln's Gettysburg Address ${ }^{11}$ ).

Another way of distinguishing his categories is temporal. The deliberative speaker focuses on the future. He or she speaks to a future event: vote for me, pass this bill, throw the rascals out. In the forensic or judicial genera, the past is what is important. The speaker "prosecutes or defends concerning what has been done." 12 In the ceremonial speech, the present tense is the primary and most important, "for all speakers praise or blame in regard to existing qualities ...."

9. Aristotle, On Rhetoric: A Theory of Civic Discourse 36 (George A. Kennedy trans., Oxford Univ. Press 1991) [hereinafter Kennedy]. Professor Kennedy's translation, extensive notes, and commentary provide the assistance needed to mine this classical work. Indeed, Kennedy's title shows the work for what it is: not only a discourse on the art of persuasion, but a work of psychological mastery that proposes a way for citizens to have the very discourse necessary for civilized society to exist.

10. E.g., Edward Rubin, Judicial Review and the Right To Resist, 97 GEO. L.J. 61, 81 n.118 (2008) ("According to Aristotle's seminal formulation, there are three types of moral government: the rule of one, or monarchy; the rule of the few, or aristocracy; and the rule of the many, which we currently call democracy.") (citing ARISTOTLE, THE POLITICS, at bk. IV (T.A. Sinclair trans., rev. ed. 1981)); Vincent J. Samar, Can a Constitutional Amendment be Unconstitutional?, 33 OKLA. CITY U. L. REV. 667, 674 (2008) (citing IRVING M. COPI \& CARL COHEN, INTRODUCTION TO LOGIC 367-68 (Sarah Touborg ed., 13th ed. 2009)) ("These are the three laws of thought, which were probably first explicitly recognized by Aristotle. They are the principle of identity, the law of contradiction, and law of excluded middle.").

11. Garry Wills, Lincoln at Gettysburg: The Words That Remade America 56-59 (1992).

12. Kennedy, supra note 9 , at 48 . Perhaps these categories are not perfectly descriptive of today's legal system which deals with remedying past events and also with correcting things moving forward.

13. Id. Again, Pericles's funeral oration shows this model. The praise was for the present: the gallantry of those soldiers who fought the battle and died, as well as those who survived and gathered at the oration. In these kinds of speeches, as Professor Kennedy notes, the "speakers usually praise past actions but with the intent of celebrating timeless virtues and inculcating them as models for the future." Id. at $48 \mathrm{n} .79$. For example, "[a]nd that government of the people, by the people, for the people, shall not perish from the earth." President Abraham Lincoln, The Gettysburg 
Aristotle goes on to list the primary "ends" or goals of the three types of speeches. The deliberative speaker speaks in terms of what is advantageous versus that which is harmful; the forensic or judicial speaker talks of the just and unjust; the ceremonial speaker evokes the honorable against the shameful. ${ }^{14}$ Mixing of these goals can occur-the deliberative speaker may claim his view is not only advantageous to society, but that the contrary view is also unjust - but the primary ends motivate the way the speech progresses. ${ }^{15}$

The most significant thing about Aristotle's contribution here is not immediately apparent because it is seemingly so obvious. His overarching theme-perhaps his greatest insight - is that one's audience is key. He is the first thinker to advance "the central idea of tailoring the argument to the knowledge and values of the audience."

Well, duh. Of course, the audience is important! That is, as the math books said when they could not figure out how to explain a concept, "intuitively obvious to even the most casual observer." But is it?

One of the greatest mistakes I see in appellate advocacy comes from confusion of this very point. Who is the audience for your appellate brief? It is not the jury; you won or lost that one below. It is not the client or even the senior partner; they are already convinced they are right. It is a judge, a very busy one with lots of work and lots on her mind, and a crushing need to get a lot of opinions out. You need to craft your advocacy accordingly. And, by the way, the bar is not doing too well at this.

Bryan Garner reports some of his research on this matter in his new book Garner on Language and Writing. His informal and admittedly anecdotal study is shocking: Judge Thomas Reavley, a highly respected jurist, put the range of helpful briefs in the Fifth Circuit at five to ten percent. ${ }^{17}$ Judge Frank Easterbrook of the Seventh Circuit, one of our most interesting judicial writers, said that it would be "extravagant to say that 3 [percent] of the briefs are of a high professional caliber."18 Another Fifth Circuit jurist, Judge Thomas Gibbs Gee, termed the brief

Address (Nov. 19, 1863), in WILLS, supra note 11, at 263.

14. Kennedy, supra note 9 , at 49.

15. Id.

16. Steven D. Jamar, Aristotle Teaches Persuasion: The Psychic Connection, 8 SCRIBES J. LEGAL WRITING 61, 65 (2002). Jamar's excellent article has been singularly helpful to me in formulating this lecture.

17. GARNER, supra note 2, at xxxiii.

18. Id. at xxxiv. 
writing he saw "[e]xecrable," and then "[h]orrible."19 Responding to those lawyers who say that if they adopt his writing suggestions the product would not be what judges expect to see, Garner says, "My answer is: precisely. You don't want to give judges what they expect. They expect boring word-gravel. They expect meandering, aimless briefs that take seemingly forever to get through. I say that you shouldn't give judges what they expect; instead, give them a pleasant surprise. ${ }^{20}$

Given this overarching theme, that the audience is important, how do we persuade it? To Aristotle there are two means of persuasion (pisteis): non-artistic (or extrinsic) and artistic (or intrinsic). ${ }^{21}$ Non-artistic refers to preexisting facts, things not provided by the speaker. An example would be "witnesses, testimony of slaves taken under torture, contracts, and such like." 22 (I wonder if they had the torture debate then too?) But important to our task are the artistic means, those embodied in the art of rhetoric and intrinsic in the rhetorician herself. This might be the most important triumvirate. Again, they are three: first, there is the character of the speaker; ${ }^{23}$ second, there is ability to dispose the listener to one's point of view, ${ }^{24}$ (or to cause the hearers to feel emotion, or, as Roberts translates, "putting the audience into a certain frame of mind" 25 ); and third, there is the argument itself. ${ }^{26}$ As a means of convenience, many scholars refer to these as ethos, the character of the speaker; pathos, the emotion of the audience; and logos, not only the words but the logic and structure of the argument. ${ }^{27}$ Let's briefly discuss each.

\section{A. Character Counts: An Advocate Should Be Fair-Minded and Credible}

The thought behind and contents of the speech should reveal a persuasive character in the speaker, presenting him or her in a

\footnotetext{
19. Id. at xxxiii.

20. Id. at xxxiv.

21. Kennedy, supra note 9 , at 37.

22. Id.

23. ARistotle, Rhetoric And Poetics 25 (W. Rhys Roberts \& Ingram Bywater trans., Random House 1954) [hereinafter Roberts \& Bywater].

24. Id.

25. Id. at 24 .

26. Id. at 25 .

27. See Kennedy, supra note 9, at 37-38 n.40 (discussing ethos and pathos). The problem is that ethos and pathos would normally be translated as moral character and emotion, which are attributes of persons, not speeches. Of course in a purely ethical world the character of the speaker would inform the character of the speech.
} 
trustworthy light. That is, the speaker should speak in a way of being "worthy of credence," 28 as some of our employment cases speak of employers' motives. Aristotle suggests that people who are thought of as fair-minded are more likely to be believed. As he says, "we believe fairminded people to a greater extent and more quickly [than we do others] on all subjects in general and completely so in cases where there is not exact knowledge but room for doubt." 29 As one writer puts it, the emphasis on character is upon the speaker gaining the audience's trust, and it is accomplished by "creating a psychological connection with the audience ....."

Aristotle is not concerned here with the reputation of the speaker, although we will be so concerned a bit later for reasons somewhat peculiar to legal advocacy. (Perhaps his lack of concern with this is because in Greek trials the defendant had to speak for himself; at best he might have someone else write a speech for him. He could not rely on a Pericles or Themistocles to present his cause.) What Aristotle is speaking to is the ability of the speaker to convey his goodness and fairmindedness by his speech. ${ }^{31}$ Additional things, such as reputation for wisdom, public service, previous actions, and others would be nonartistic or extrinsic, and so not the subject of our current inquiry. Aristotle parts company with some of his contemporaries here: "It is not true, as some writers assume in their treatises on rhetoric, that the personal goodness revealed by the speaker contributes nothing to his power of persuasion; on the contrary, his character may almost be called the most effective means of persuasion he possesses." 32

While it is true that judges today cannot (and should not) expressly punish a party for an advocate's bad character, character still contributes something. Like it or not, character and argument are, as Ari notes, inextricably intertwined. While a judge may not consciously assess the value of a brief based on the character of the lawyer, if a lawyer throws in ten meritless arguments and buries a good one in the middle, a judge

\footnotetext{
28. Id. at 38 .

29. Id.

30. Jamar, supra note 16 , at 73 .

31. The character of the speaker may be even more important in the ceremonial epideictic occasions that call for encomia. In Book I, chapter nine, Aristotle lists the virtues worthy of study so that we can find "how to make our hearers take the required view of our own characters...." Roberts \& Bywater, supra note 23, at 56. The list includes "justice, courage, temperance, magnificence, magnanimity, liberality, gentleness, prudence, [and] wisdom." Id. at 57. And, Aristotle also suggests how to adapt the praise form of the epideictic oratory into the judicial setting, where it might be needed as the speaker (the defendant himself in the Greek setting) might be under suspicion. Id. at 59-63.

32. Id. at 25 .
} 
will be less inclined to believe the good one than if it had been the only argument put forward, and will have reason to doubt the "goodness" and "fair-mindedness" of the advocate. An advocate who is caught playing fast and loose with the record should not be surprised if the court questions his arguments. ${ }^{33}$ Likewise, a frank but appropriate concession or providing the court with authority contrary to your position (and attempting to distinguish it fairly) enhances reputation. Answering hypotheticals fairly does the same. The examples are admittedly drawn from appellate practice, but the ethos, pathos, and logos concepts are equally instructive for proper advocacy before a jury.

At a later point in his treatise, Aristotle discusses three reasons (again the "rule of three!"), aside from logic, why speakers are persuasive, "for there are three things we trust other than logical demonstrations." 34 They are practical wisdom (or perhaps prudence), virtue (excellence), ${ }^{35}$ and good-will. ${ }^{36}$ His text again bears quoting:

[S]peakers make mistakes in what they say or advise through [failure to exhibit] either all or one of these; [] for either through lack of practical sense they do not form opinions rightly; or though forming opinions rightly they do not say what they think because of a bad character; or they are prudent and fair-minded but lack good will, so that it is

33. As Judge Frank Coffin explained:

When I pick up a brief, the first thing I look for is the name of the attorney or the firm. This is generally a neutral exercise. I may not know or have heard of the writer of the brief or the firm. Or, if I do have some memory, it may be unilluminating. But I must confess that if I associate the name with earlier briefs and arguments that were misleading, useless, or otherwise unreliable, I start with a special wariness. By the same token, if the name recalls to me earlier candid, competent, and highly professional performances, I relax and prepare to enjoy the experience.

Frank M. CofFin, On APPEAl: Courts, LaWyering, and Judging 111 (1994). Interestingly, the venerable Judge Coffin also notes that a judge's name can be important:

My next inquiry is to find out who was the judge in the trial court. This, too, is quite an irrelevant quest for the most part. Yet I cannot deny that my prior experience has something to do with attitude at the outset of the consideration of an appeal. Most of the time, a particular trial judge would stand in my mind for an unremembered set of rulings, most of them sound, a few of them found reversible. But I might remember a judge as the author of rulings rather consistently reversed by the appellate court. I cannot help approaching an appeal from such a judge with a slight skepticism. Finally there are trial judges who stand out in my mind as consistently open, sensitive, careful, and splendid. Here, too, I am afraid I tend to begin with a bias, predisposed to think that reversal is not Id. likely.

34. Kennedy, supra note 9, at 120-21.

35. See id. at 79 n.160 (explaining Aristotle's use of excellence).

36. Id. at 121 
possible for people not to give the best advice although they know [what] it [is].

Although prudence and virtue are philosophic matters that the speaker must acquire through study and practice, good-will comes from the emotional aspect, the pathos.

\section{B. An Advocate "Stirs the Emotions" of His Audience}

Aristotle's second means of persuasion, often called pathos, deals with stirring the emotions of the audience. ${ }^{38}$ "Our judgments when we are pleased and friendly are not the same as when we are pained and hostile." ${ }^{39}$ Most of the rhetoricians of his day seemed to emphasize this emotive part of rhetoric to the exclusion of just about everything else. Aristotle realizes that "among human beings judgment is not entirely a rational act. There are morally valid emotions in every situation, and it is part of the orator's duty to clarify these in the minds of the audience." 40

In Book II, Aristotle turns to the character of the audience, and how to understand and excite certain emotions. These chapters have been termed "the earliest systematic discussion of human psychology," and seek to provide the speaker with both an understanding of his audience, and the ability to arouse emotions in such an audience. ${ }^{41}$ These fascinating discussions are in positive and negative pairings, and reflect how little human beings have changed. They include discussions on

37. Id. See also Roberts \& Bywater, supra note 23 , at 91 ("[O]r finally, they are both sensible and upright [i.e., have prudence and virtue] but not well disposed to their hearers, and may fail in consequence to recommend what they know to be the best course.").

38. I want to note here that a panel of appellate judges is not the audience that a jury is.

39. Roberts \& Bywater, supra note 23 , at 25 .

40. Kennedy, supra note 9 , at 39 n.45. Economists are coming to recognize our preferences are not entirely rational, perhaps witnessing what Aristotle observed so long ago. As two economists explained in a recently published book:

John Maynard Keynes sought to explain departures from full employment, and he emphasized the importance of animal spirits. He stressed their fundamental role in businessmen's calculations. "Our basis of knowledge for estimating the yield ten years hence of a railway, a copper mine, a textile factory, the goodwill of a patent medicine, an Atlantic liner, a building in the City of London amounts to little and sometimes to nothing," he wrote. If people are so uncertain, how are decisions made? They "can only be taken as a result of animal spirits." They are the result of "a spontaneous urge to action." They are not, as a rational economic theory would dictate, "the outcome of a weighted average of quantitative benefits multiplied by quantitative probabilities."

George A. Akerlof \& Robert J. Shiller, Animal Spirits: How Human Psychology Drives THE ECONOMY, AND WHY IT MATTERS For GlobAl CAPITALISM 3 (2009) (citation omitted).

41. Kennedy, supra note 9, at 122. 
anger and calmness; friendliness and hostility; fear and confidence; shame and shamelessness.

In chapters twelve through seventeen of Book II, Aristotle blends a bit of pathos and ethos as he attempts to teach the speaker how to adapt his character to that of the audience in order to get their attention and emotion. Although some of these characterizations may seem a bit politically incorrect today, I want to offer a couple of them to you to show the technique the Great Philosopher was able to use, and to suggest again that studying the character of the audience and molding the character of the speaker are vitally important to advocacy.

In characterizing the young, Aristotle says this:

[T] he young are prone to desires and inclined to do whatever they desire. Of the desires of the body they are most inclined to pursue that relating to sex, and they are powerless against this.... They are changeable and fickle in desires, and though they intensely lust, they are quickly satisfied; for their wants, like the thirst and hunger of the sick, are sharp rather than massive .... And they are impulsive and quick-tempered and inclined to follow up their anger [by action]. And they are unable to resist their impulses; for through love of honor they cannot put up with being belittled but become indignant if they think they are done a wrong.... And though they love honor, they love victory more; for youth longs for superiority, and victory is a kind of superiority.

Oh, for the days when I was too young to resist my impulses! But, compare the above with his characterizations of the old:

People who are older and more or less past their prime have characters that are for the most part the opposite of these [just described]; for through having lived for many years and having been more often deceived and having made more mistakes themselves and since most things turn out badly, they assert nothing with certainty and all things with less assurance than is needed. [] And they "think," but do not "know" anything. And being doubtful, they always add perhaps and maybe and say everything that way, but nothing definitively. [] And they are cynical; for a cynical disposition supposes everything is for the worse. Further, they are suspicious because of their distrust and distrustful because of experience .... And they are stingy; for one of the necessities is money, and at the same time they know from experience that it is difficult to acquire and easy to lose. [] And they are cowardly and fearful ahead of time about everything; for their disposition is the opposite of the young. (They are chilled, but the young are hot, so old age has prepared the way for cowardice; for fear

42. Id. at 165 . 
is a kind of chilling.) [] And they are fond of life and more so in their last day because of the presence of desire for what is gone, and people most desire what they lack.... And they expect the worst, through experience - [in their view] the greater part of things that happen are bad; at least most turn out for the worse - and through their cowardice, too. [] And they live in memory more than in hope; for what is left of life is short, what is past is long, and hope is for the future, memory for what is gone. This is the cause of their garrulity; for they keep talking about things that have passed; for they take pleasure in reminiscence .... Such are the characters of the young and the older; as a result, since all people receive favorably speeches spoken in their own character and by persons like themselves, it is not unclear how both speakers and speeches may seem to be of this sort through use of words.

Ouch! I have shared these paragraphs with many, and most agree they hit a little too close to home. A serious student of rhetoric can mine a lot from this canny understanding of potential audiences.

Advocates, I included this material both to show you the lengths Aristotle went to categorize and identify with his audiences and to show that human nature does not change all that much. But let me specifically relate it to the task at hand-persuading judges whether young or old.

Now we judges, believe it or not, prefer to do what is just (as we see it). But, you are likely to get a stern rebuke, particularly from an appellate judge, if you appeal to "justice" standing on its own. Keep in mind, an appeal to justice must be firmly grounded in the law. In an appeal some months ago, a lawyer began his argument to our panel, in a loud voice and with a flourish, thusly: "I have come to this court to demand justice!" But the presiding judge thought he had better nip this in the bud and get the lawyer to the real task at hand, and simply said: "Well, you've come to the wrong place then. We do law up here. Let's talk about that."

\section{An Advocate Presents a Logical and, Hence, Probable Argument}

The third means is logic. Ari's opening salvo on the means of persuasion often termed logos, dealing with the actual argument itself, is remarkably terse: "Thirdly, persuasion is effected through the speech itself when we have proved a truth or an apparent truth by means of the persuasive arguments suitable to the case in question." ${ }^{44}$ After this introduction he returns to the subject time and time again, for it is clearly

43. Id. at $167-68$.

44. Roberts \& Bywater, supra note 23 , at 25 . 
what he was, and I suggest what we should be, most concerned with. Now let me hurriedly say that I am not a logician; like many of you, the avoidance of mathematics drove me to law school. But like all the experts of legal writing that I have consulted, I think logic is essential to the successful practice of advocacy.

The following concepts, like the idea of concentrating on one's audience, are not necessarily earth-shattering. We use them all the time perhaps without intending to and certainly without telegraphing their use. Nonetheless, it is helpful to identify logical concepts so we have a better understanding of how to use them.

The logic to be used in Ari's rhetoric comes essentially in two forms: induction and deduction. ${ }^{45}$ The first is induction (also called "paradigmatic" reasoning, and related to reasoning by example and reasoning from "part to part" as in analogy). ${ }^{46}$ Inductive reasoning is a form of logic in which lasting, general principles are discovered from studying the outcomes of many small events. Suppose that one month ago you gave your dog Spike a Snickers bar and he became violently ill. Three weeks ago you gave him some Hershey's Kisses, and the same thing happened. Last week he lost it when you gave him a Three Musketeers, and yesterday he projected upon receiving a Reese's Peanut Butter Cup. Using induction, you might reason that you should quit giving your dog chocolate, unless you are a non-risk-averse canine sadist, willing to be convicted of animal cruelty.

The hard part - the real art — of inductive reasoning is knowing when you have found a sufficient number of examples to craft a sweeping rule.

45. A third type of reasoning is "abductive" reasoning, which uses an inference to get from point A to point B. Abductive reasoning does not necessarily prove anything, but rather relies on a logical jump from something known to something unknown (but that seems likely). As Sherlock Holmes explained after using his observations of pocket-watch to correctly infer the character of its former owner:

"Ah, that is good luck. I could only say what was the balance of probability. I did not at all expect to be so accurate .... What seems strange to you is only so because you do not follow my train of thought or observe the small facts upon which large inferences may depend."

Arthur Conan Doyle, The Sign OF Four 7-8 (Book-of-the-Month Club ed. 1994) (1889).

46. "The basic pattern of legal reasoning is reasoning by example." EDWARD H. LEVI, AN INTRODUCTION TO LEGAL REASONING 1 (1949) (“"[T]o argue by example is neither like reasoning from part to whole, nor like reasoning from whole to part, but rather reasoning from part to part, when both particulars are subordinate to the same term and one of them is known. It differs from induction, because induction starting from all the particular cases proves ... that the major term belongs to the middle and does not apply the syllogistic conclusion to the minor term, whereas argument by example does make this application and does not draw its proof from all the particular cases." (quoting ARISTOTLE, ANAlytiCA PRIORA 69a (McKeon ed., 1941))). Perhaps a related form of reasoning is abduction, in which one essentially takes a set of observed phenomena and forms a hypothetical explanation. 
The number of instances of observed sickness in Spike might not be enough to conclude by induction that giving him chocolate will always make him sick. It could be white sugar, and not chocolate, that makes your best friend sick. But, I suspect that we would think our rule close enough for government work; even Aristotle suggests that inductive logic may be thought of in terms of probabilities rather than inescapable conclusions. $^{47}$

In law, we use inductive reasoning in several ways. As I indicated above, sometimes we might use it to determine the general rule which we will later apply syllogistically. Judge Aldisert shows this in his article by suggesting that the famous syllogism "All men are mortal; Socrates is a man; Therefore, Socrates is a mortal" is based upon induction. ${ }^{48}$ How do we know the general rule that "all men are mortal?" Plato, Caesar, Washington, John Marshall, Ronald Reagan, and George Carlin were all men, and all mortal, therefore, we can divine a rule that all men eventually die. Another example would be the reasoning in Brown v. Board of Education. ${ }^{49}$ The Supreme Court examined findings by various district courts involving specific cases, as well as sociological studies involving discrete samples, to determine generally that " $[\mathrm{t}] \mathrm{o}$ separate [children] from others of similar age and qualifications solely because of their race generates a feeling of inferiority as to their status in the community that may affect their hearts and minds in a way unlikely ever to be undone." 50 Thus, the Court held that separate schools based on race are constitutionally impermissible under the Equal Protection Clause. ${ }^{51}$

Another example occurs in a statutory construction matter. Suppose the rule is "no vehicles are allowed on the sidewalks in the park." 52 Officer O'Brady, on a bad day perhaps, cited Ms. Murphy with a violation of the ordinance because she wheeled her baby carriage through the park. In arguing that "vehicle" has a certain meaning, you might show that the ordinance has been applied to motorcycles, bicycles, scooters, and skateboards. Your research might then demonstrate that no jurisdiction - not one - has defined baby carriages or walkers (let's try to

47. See Kennedy, supra note 9, at 40-41.

48. Ruggero J. Aldisert et al., Logic For Law Students: How To Think Like A Lawyer, 69 U. PITT. L. REV. 1, 3-4 (2008).

49. 347 U.S. 483 (1954).

50. Id. at $494 \&$ nn. $10-11$.

51. Id. at 495 .

52. See H.L.A. Hart, Positivism and the Separation of Law and Morals, 71 HARV. L. REV. 593, 607 (1958) (asserting that the law is affected by the "penumbra of debatable cases" in which words carry multiple meanings). For a reply to Hart's thesis, see Lon L. Fuller, Positivism and Fidelity to Law-A Reply to Professor Hart, 71 HARV. L. REV. 630, 662-64 (1958). 
pick up some pathos here!) as a vehicle. So, inductively, you would argue this statute could not be meant, and should not be construed, to apply to Ms. Murphy. ${ }^{53}$

Although inductive reasoning has important implications for the law, the second category of logic, deduction (reasoning from a general to a particular) is really the glue that holds good advocacy together. The syllogism is an example of deductive reasoning. Understanding the syllogism is the most important lesson to gain from Aristotle's three means of persuasion. Remember our friend Spike the Dog. Imagine that before Spike ever gets near a Snickers bar you examine some veterinary literature and you find a general proposition that all dogs are allergic to chocolate and will become violently ill if given even a small portion of it. You might then construct a deductive syllogism with its requisite major premise, minor premise, and conclusion: All dogs are allergic to chocolate; Spike is a dog; Spike is allergic to chocolate. Your major premise - the general statement covering many cases - is that all dogs are allergic to chocolate. The minor premise-a particular fact statement-is that good ol' Spike is a dog. The conclusion ineluctably follows if the major and minor premise are true.

Any advocate, with a little work and practice, should be able to either develop enough character (or conceal it) in order to get a fair shake before jury, judge, judges, or justices. Likewise, although juries are usually more susceptible to pathos than judges, if you studiously and intelligently keep the right audience in mind, you should be on equal footing with your adversary. But it is in the logic of your arguments, and specifically your syllogisms, that you can produce overcoming advocacy.

This is why Bryan Garner, in his excellent book, The Winning Brief, entitles chapter eleven as follows: "Write fair but persuasive issues that have only one answer. Cast each issue as a syllogism. If you have

53. Or, as Professor Fuller explained, the purpose of the statute can be useful here. If the purpose were to protect children from being injured by vehicles, it is not illegal for the ambulance to drive through the park to transport an injured child. Fuller, supra note 52, at 663 ("It is rather because, for example, whether the rule be intended to preserve quiet in the park, or to save carefree strollers from injury, we know, 'without thinking,' that a noisy automobile must be excluded."). But see Hart, supra note 52, at 607 ("[I]n applying legal rules, someone must take the responsibility of deciding that words do or do not cover some case in hand with all the practical consequences involved in this decision."). In his effort to preserve the utilitarian separation of law and morals, Hart uses the example to concede a distinction between "core" and "penumbral" meanings of words (like "vehicle" in the park example). Id. at 607-15. Fuller, in his effort to show a deeper connection between law and morals, uses the example to show that we routinely consult the purpose behind laws in order to determine their appropriate application. Fuller, supra note 52, at 663-69. 
several issues, give each one a concise, neutral heading." ${ }^{, 54}$ Here is his specific advice:

A good issue statement generally mirrors a syllogism - the basis of all logical thought. You have a major premise stating the law, a minor premise presenting the facts that tie into that major premise, and a conclusion. But when cast as part of an issue statement, the conclusion becomes a question.

Yes, the best issues end with question marks. Why?

Because a bona fide question looks and sounds objective even when it's gently slanted. Rather than pushing your answer, you're putting a question on the table. You're also challenging your opponent to explain how the answer could be other than as you're suggesting. You're seizing the issue - and, as a rule, the side that successfully does that will win ....

So Garner gives a specific formula: the major premise is the controlling point of law; the minor premise is your specific factual scenario that ties into that legal point; and the conclusion is expressed (with some ethos and pathos in mind) as a question.

Here is a very simple possible example from the recent case District of Columbia v. Heller, ${ }^{56}$ which re-armed our nation's capital. The District of Columbia generally prohibited the possession of handguns by making it a crime to carry an unregistered firearm and then prohibiting registration of handguns, subject to minor exceptions. ${ }^{57}$

The Respondents, challenging the ordinance, might frame their proposition this way:

Major Premise: The Second Amendment to the United States Constitution states in pertinent part that the right of the people to keep and bear arms shall not be infringed.

Minor Premise: The District of Columbia's ordinance generally prohibits possession of handguns, which are "arms."

54. Bryan A. Garner, The WinNing Brief 85 (2d. ed. 2004)

55. Id. at 86 .

56. 128 S. Ct. 2783 (2008).

57. Id. at 2788 . 
Conclusion or Question: Does the District of Columbia's ordinance violate the Second Amendment? ${ }^{58}$

The Petitioners might proceed as follows:

Major Premise: The Second Amendment necessarily relates the right to possession and bearing of arms to the existence and operation of a "well-regulated militia."

Minor Premise: The District of Columbia does not have a militia, and its ordinance does not restrict militia-related firearms.

Conclusion or Question: Does the ordinance violate the Second Amendment? ${ }^{59}$

This kind of reasoning pervades law and legal advocacy. Even without knowing it, lawyers do much of it naturally. Syllogisms are used all the time, and for good reason. Using thoughtful and concise syllogisms ensures that each conclusion is buttressed with sufficient evidence, and gives a judge a clear trail of breadcrumbs to follow as he wanders through your brief.

So in conclusion of the middle, let me remind you of a couple of Aristotle's threesomes. Speeches are of essentially three types, based upon the audience addressed: deliberative, judicial, or ceremonial. The means of artistic persuasion-the ones unlike witnesses and torture that you can control-are also three: the ethos or character of the speaker, the emotion or pathos of the audience, and the logic or probability of the argument. Good advocates think about these things.

\section{The EnD: But ReputATIOn Counts, ToO: An Advocate Must BE ETHICAL}

In closing, let me remind you that earlier, in discussing the character of the speaker, I pointed out that Ari was not concerned with the previous reputation of the speaker in his teachings of rhetoric. But, I said that there is a difference in law, and that difference is critical. It is, in my view, why a center for advocacy needs to be centered at a law school, but must involve the active participation of the bar.

The reputation of a legal advocate is important. Lawyers are officers of the court. Each time they argue before a judge, their reputation is at 
stake. And ethical advocacy among the practicing bar is essential for another reason. The bar is not only being watched by the judges; and judges are not only being watched by judges and the bar. Aristotle focuses on how the advocate (partly because of the structure of Greekcitizen advocacy) creates an instant reputation as he argues; Ari presumes that the judge or jury does not know the advocate. ${ }^{60}$

Larry Hellman, now the Dean of the Oklahoma City University Law School, studied the experiences of law students who work in law offices while they are attending law school (as part-time interns or summer clerks, for example) in an influential empirical study done about twenty years ago. ${ }^{61}$ He found that the law students were exposed surprisingly frequently to serious violations of the written standards of the profession by lawyers, and even judges, who they encounter in their practice environments. His study demonstrated that, for many students, this exposure to inappropriate conduct is a more powerful influence than law school instruction on law students' understanding of what constitutes professionally appropriate conduct. ${ }^{62}$

A chapter he has written for a forthcoming book summarizes: "This study demonstrated that a student's practice environment quickly supersedes law school as a source of reference for demarcating professionally acceptable behavior."

Finally, the extent of negative role-modeling encountered in law practices was shocking:

It is difficult to overstate the extent to which the students in my study were subjected to inappropriate professional conduct that appeared to be condoned by those with whom they practiced. Over 60 percent of the working students were exposed to at least one instance of flagrant professional misconduct, often within the very offices where they worked. Many students saw a lawyer lie, cheat, steal, or disserve a client, frequently doing so as if this were 'business as usual' in the legal profession. Perhaps the most disturbing fact to be drawn from the tabulation of these episodes is that the most frequently reported types of violations involved some of the rankest forms of professional

60. Michael H. Frost, introduction to Classical Legal Rhetoric: A lost Heritage $58-59$ (2005)

61. Lawrence K. Hellman, The Effects of Law Office Work on the Formation of Law Students' Professional Values: Observation, Explanation, Optimization, 4 GeO. J. LeGAL ETHICS 537 (1991).

62. Id. at 543-44.

63. Lawrence K. Hellman, Carnegie's Missing Step: Prescribing Lawyer Retraining, in REAFFIRMing LEgal ETHICS: TAKING STOCK AND NEW IDEAs (Reid Mortensen et al. eds., 2009) (forthcoming Dec. 2009) (citing Lawrence K. Hellman, The Effects of Law Office Work on the Formation of Law Students' Professional Values: Observation, Explanation, Optimization, 4 Geo. J. LEGAL ETHICS 537, 611 (1991)). 
misconduct: dishonesty (29 apparent violations), breaches of confidentiality (19), excessive fees (21), and neglect (18). Disregard for the conflict of interest rules was surprisingly widespread (40 apparent violations). Though fewer in number, the frequency of some other categories of gross misconduct is also alarming: frivolous claims and defenses (10 apparent violations), abuse of prosecutorial discretion (8), candor to tribunal (7), bribery (2), and destruction of evidence (2). A total of 296 apparent violations were observed by the 66 students who participated in the [study]. Students clearly recognized that compliance with the legal profession's self-regulatory ideal was rare. ${ }^{64}$

Dean Hellman's study was echoed in 1992 by the influential MacCrate Report, published by a special task force of the American Bar Association. As the report noted:

Law schools can, and should, teach [the fundamental professional] values in clinical and traditional courses and should instill in students the desire to achieve them in the course of their professional careers. The efforts of the law schools, however, will mean little if the practicing bar shuns its own responsibilities for inculcating professional values. Practicing lawyers can teach by the power of example. ${ }^{65}$

As Judge Frank Coffin noted in his wonderful book, On Appeal, the most important thing in a brief may be that which is on the front page: the name of the advocate. ${ }^{66}$ If an advocate becomes known for the maladies indicted in Dean Hellman's study, he or she may have a very tough row to hoe. If the name on the brief recalls that kind of advocate-one known for poor writing or speaking, for denigrating opposing counsel, or attacking the character of the judge below-the brief may go to the bottom of the stack, the argument to the heel of the docket. ${ }^{67}$ In short, such lawyers, in addition to violating their ethical code, are simply forgetting Aristotle's most important point: it's the audience, stupid!

So, in conclusion, Aristotle has taught us the importance of the advocate's character and the importance of the advocate's logical arguments. ${ }^{68}$ But again, the audience is the key: exhibiting character and

64. Id. (citations omitted).

65. Am. Bar Ass'N Section on Legal Educ. And Admission to the Bar, Legal

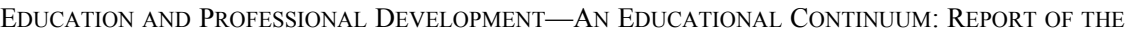
TASK FORCE ON LAW SCHOOLS AND THE PROFESSION: NARROWING THE GAP 235-36 (1992).

66. See CoffIN, supra note 33.

67. Judge Coffin is not abandoning the judge's obligations to be fair, but is merely pointing out how it can be more difficult to be fair in these situations. $I d$.

68. Roberts \& Bywater, supra note 23, at 24-25. 
reasoning crafted to the audience at hand-knowing the audience and doing all that you can to develop its trust.

And that is why we are fortunate to be here. For we are three ourselves: the academy, the advocates, and the audience. The academy has the capacity to be an invaluable liaison between advocates and their primary audience, judges. What better way for these three groups to teach and learn from each other, than through a center like the Shook, Hardy and Bacon Center for Excellence in Advocacy? (And by the way, we judges need to improve our persuasive skills, too!) This fine law school is fortunate to dedicate this endeavor today, and to serve not only as an ivory tower but also as an ivory bridge. 